\title{
ZMIANA KRĘGU SPADKOBIERCÓW - IMPLIKACJE DLA POSTĘPOWANIA CYWILNEGO I PODATKOWEGO
}

\author{
Anna Hnatów, anna.hnatow@gmail.com \\ Uniwersytet im. Adama Mickiewicza w Poznaniu \\ Wieniawskiego 1, 61-712 Poznań
}

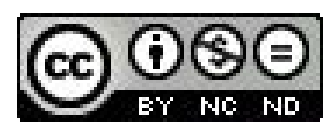

\section{STRESZCZenie}

Zmiana kręgu spadkobierców wywołuje konsekwencje nie tylko w prawie cywilnym, ale także w postępowaniu cywilnym oraz postępowaniu podatkowym. W artykule starano się przedstawić powyższe konsekwencje, w szczególności w postępowaniu z art. 679 KPC oraz postępowaniu podatkowym w przedmiocie ustalenia podatku od spadków i darowizn.

Słowa kluczowe: spadkobiercy, postępowanie cywilne, postępowanie podatkowe, nabycie spadku

\section{Changing the circle of heirs - implications for civil and tax proceedings}

\section{Abstract}

Changing the heirs causes consequences not only in civil law, but also in civil and tax proceedings. The article aims to show these consequences, especially in dealing with the art. $679 \mathrm{KPC}$ and tax proceedings relating to the determination of inheritance tax.

Key words: heirs, a civil proceedings, a tax proceedings

\section{WsTĘP}

W przypadku dziedziczenia dochodzi do ustalenia kręgu spadkobierców, którzy na mocy prawa w drodze sukcesji uniwersalnej wstępują w ogół praw i obowiązków majątkowych spadkodawcy, nabywającje z chwiląjego śmierci. W celu stwierdzenia nabycia spadku przeprowadzone jest postępowanie odrębne w trybie nieprocesowym w oparciu o art. 669679 Kodeksu postępowania cywilnego (dalej KPC), w wyniku którego sąd wydaje postanowienie o nabyciu spadku przez spadkobierców. Umożliwia to osobom widniejącym w wyżej wskazanym postanowieniu korzystanie z domniemania prawnego zawartego w art. 1025 § 1 Kodeksu cywilnego (dalej KC) oraz wystąpienie do organu podatkowego o ewentualne wszczęcie postępowania w celu ustalenia należnego podatku od spadków na mocy ustawy z dnia 28 I $1983 \mathrm{r}$. o podatku od spadku i darowizn (Dz. U. 2009 nr 93, poz. 768 -j. t., ze zm.). W trakcie postępowania podatkowego organ może powziąć informacje o okolicznościach uzasadniających ustalenie innego niż wskazany w postanowieniu o nabyciu spadku kręgu spadkobierców. Wskutek tego w zależności czy stały się znane przed wydaniem decyzji ustalającej podatek od spadków i darowizn czy po jej uprawomocnieniu może dojść do zawieszenia postępowania lub nawet do jego wznowienia.

Niniejszy artykuł ma na celu przedstawienie przede wszystkim implikacji dla spadkobierców na gruncie postępowania cywilnego oraz postępowania podatkowego w sytuacji, gdy dochodzi do zmiany kręgu spadkobierców lub wysokości ich udziałów w spadku. Autorka starała się ukazać również funkcję pełnioną przez analizowane regulacje prawne, które związane są nie tylko z ochroną praw przyznanych spadkobiercom $\mathrm{w}$ prawie materialnym, ale $\mathrm{w}$ dużej mierze $\mathrm{z}$ ustaleniem takiego stanu prawnego, który odpowiada rzeczywistości. Z tego względu zostały przedstawione $\mathrm{w}$ artykule konsekwencje wynikające z uzyskania stwierdzenia nabycia spadku w prawie cywilnym, szczególnie domniemania odgrywające istotną rolę $\mathrm{w}$ postępowaniu sądowym oraz postępowaniu przed organem podatkowym, o czym mowa w dalszej części pracy. Następnie szczegółowo ukazane zostały w ramach wyżej wskazanych postępowań dwa przypadki, mianowicie - gdy okoliczności powodujące zmianę kręgu spadkobierców staną się wiadome przed wydaniem postanowienia o nabyciu spadku lub decyzji ustalającej podatek od spadków i darowizn oraz po ich uprawomocnieniu, co pozwoli zobrazować kompleksowość, spójność wspomnianych regulacji oraz najlepiej uwidoczni funkcję nadaną im przez ustawodawcę. Powyższe kwestie zostały przedstawione na przykładnie postanowienia o nabyciu spadku, pominięto zaś problematykę prawną związaną z aktem poświadczenia dziedziczenia. 


\section{Prawna doniosŁość STWIERdZenia NABycia SPADKU}

Na mocy art. 925 KC spadkobierca nabywa spadek z chwilą otwarcia spadku, którą wyznacza chwila śmierci spadkodawcy. Zgodzić należy się ze stwierdzeniem, iż wspomniany art. $925 \mathrm{KC}$ wyznacza wprawdzie moment przejścia na spadkobiercę określonych w art. $922 \mathrm{KC}$ praw i obowiązków majątkowych, niemniej na podstawie tego przepisu nie można stwierdzić kto i w jakiej części nabył spadek ${ }^{1}$. W tym celu należy ubiegać się o uzyskanie urzędowego potwierdzenia nabycia spadku, które wiąże się z wzięciem udziału w postępowaniu przed powołanym do tego organem, którym zgodnie z przepisami prawa jest sąd - na podstawie ustawy z dnia 17 XI 1964 r. kodeks postępowania cywilnego (Dz. U. z 1964r. nr 43 poz. 296 - j. t. ze zm.) lub notariusz na podstawie przepisów ustawy z dnia 14 II 1991 r. prawo o notariacie (Dz. U. $1991 \mathrm{nr} 22$ poz. 91 z późn. zm.). Osoba uważająca się za spadkobiercę może więc wybrać jedną z dwóch dróg prowadzących do poświadczenia nabycia spadku, a to którą z tych dwóch wybierze zależy od szeregu okoliczności faktycznych. W wyniku przeprowadzenia postępowania zostaje wydany dokument poświadczający dziedziczenie oraz informujący w jakim udziale określona osoba jest spadkobiercą. Dokumentem tym jest:

- $\quad$ wydane przez sąd postanowienie o nabycia spadku,

- $\quad$ akt poświadczenia dziedziczenia, sporządzony przez notariusza.

Urzędowe stwierdzenie dziedziczenia posiada ogromną doniosłość prawną. Od tej chwili osoba twierdząca, że jest spadkobiercą może w świetle prawa występowaćjako spadkobierca, gdyżjej prawa do spadku zostały udowodnione inie budzą wątpliwości. Równocześnie osoba, która nie figuruje w postanowieniu o stwierdzeniu nabycia spadku lub w akcie poświadczającym dziedziczenie nie może być uznana za spadkobiercę, choć może dochodzić swoich praw w postępowaniu cywilnym. W tym miejscu warto dodać, że niektórym osobom może zależeć na wykazaniu, że nie są spadkobiercami w sytuacii, gdy spadek został obciążony długami. Ze stwierdzeniem nabycia spadku związane jest domniemanie zawarte w art. 1025 § 2 KC, według którego osoba, która uzyskała stwierdzenie nabycia spadku lub poświadczenie dziedziczenia jest spadkobiercą. Warto zwrócić uwagę na fakt, iż opisane w zdaniu poprzednim domniemanie rozciaga się również na wielkość udziałów przypadających konkretnym spadkobiercom². Domniemanie to można obalić specjalnym rodzajem przeciwdowodu, który wiąże się z przeprowadzeniem odrębnego postępowania sądowego według art. 679 Kodeksu postępowania cywilnego, o czym będzie mowa w dalszej części artykułu.

Najczęściej do stwierdzenia nabycia spadku dochodzi, gdy spadkobiercy pragną dokonać podziału spadku, co jest niemożliwe bez stwierdzenia w jakiej części dziedziczą. Na podstawie art. 680 KPC można dojść do wniosku, że postanowienie o nabyciu spadku lub zarejestrowany akt poświadczenia dziedziczenia, a także spis inwentarza wraz z informacją o sporządzonych testamentach powinny zostać powołane przez wnioskodawcę w postępowaniu w przedmiocie działu spadku. W przypadku, gdy wnioskodawca nie dysponuje postanowieniem o nabyciu spadku lub zarejestrowanym aktem poświadczenia dziedziczenia, można wyróżnić pogląd w doktrynie, według którego wniosek o dokonanie działu spadku skierowany do sądu zawiera ponadto żądanie stwierdzenia nabycia spadku. Wówczas sąd wydaje postanowienie o nabyciu spadku w trakcie postępowania działowego (art. $681 \mathrm{KPC}$ ).

Ponadto na mocy art. 1036 KC spadkobierca do chwili działu spadku ma prawo, za zgodą pozostałych spadkobierców, do rozporządzenia swoim udziałem w spadku. Dokument potwierdzający nabycie spadku może wówczas służyć w celu dowodowym, by wykazać, że dana osoba jest spadkobiercą i ma prawo rozporządzać przypadającym na nią udziałem w majątku spadkowym. Wskazane dokumenty potwierdzające dziedziczenie pozwalają również udowodnić wobec osób trzecich, nie roszczących prawa do przedmiotu spadku, swoje prawa (na mocy art. $1027 \mathrm{KC}$ ). Należy jednakże zauważyć, iż ustawodawca w niniejszym przepisie ustanowił wyraźnie, że udowodnienie praw spadkobiercy związanych z dziedziczeniem może nastąpić tylko i wyłącznie za pomocą postanowienia o stwierdzeniu nabycia spadku lub aktu poświadczenia dziedziczenia. A contrario można więc uznać, że używanie w tym celu innych dowodów, np. testamentu spadkodawcy nie uprawnia do zastosowania domniemania zgodności stwierdzonych w nim faktów ze stanem prawnym i nie upoważniają do traktowania takiej osoby jak spadkobiercy, nie mają więc one charakteru legitymacyjnego. Również osoba, która nabyła daną rzecz od osoby niebędącej spadkobierca, ale legitymującą się aktem poświadczenia dziedziczenia lub stwierdzeniem nabycia spadku korzysta z ochrony prawnej, przyznanej jej przez normę wyrażoną w art. 1028 KC. Konstrukcja przewidziana w art. 1028 KC pozwala na ochronę obrotu prawnego poprzez przyznanie legalności i skuteczności nabycia prawa od osoby nieuprawnionej, jeśli spełnione są przesłanki wymienione w ustawie,

1 E. Skowrońska-Bocian, Prawo spadkowe, Warszawa 2012, s. 141.

2 K. Osajda (red.), Kodeks cywilny. Komentarz, Warszawa 2013. 
wskutek czego uznawana jest za szczególny przypadek nabycia prawa od nieuprawnionego ${ }^{3}$. Należy w tym miejscu wyraźnie podkreślić, iż ochroną wynikającą z art. 1028 KC objęte są tylko i wyłącznie czynności rozporządzające, co ma istotne znaczenie w przypadku nabycia przedmiotu wchodzącego w skład spadku od osoby nieuprawnionej, o czym będzie mowa w dalszej części artykułu.

\section{ZMIANA KRĘGU SPADKOBIERCÓW W TRAKCIE POSTĘPOWANIA O STWIERDZENIU NABYCIU SPADKU}

Na podstawie rozważań przedstawionych $\mathrm{w}$ poprzednim rozdziale można stwierdzić, iż postanowienie o nabyciu spadku posiada ogromną doniosłość prawną. Z tego względu ustawodawca w przyjętych przez siebie uregulowaniach prawnych dążył do tego, by wydane przez sąd postanowienie odzwierciedlało wiernie stan faktyczny. Kodeks postępowania cywilnego (w przepisach regulujących postępowanie w przedmiocie stwierdzenia nabycia spadku) zawiera rozwiązania prawne, mające na celu ograniczenie sytuacji, gdy stan faktyczny związany z dziedziczeniem odbiega od stanu prawnego ustalonego przez sąd. Wspomniane mechanizmy mają za zadanie przede wszystkim pozwolić na ustalenie rzeczywistego kręgu spadkobierców i zapisobierców windykacyjnych oraz umożliwić wydanie zgodnego z prawdą materialną orzeczenia, w przypadku gdy do zmiany kręgu spadkobierców dochodzi w trakcie postępowania.

Wspomniano wcześniej, iż w celu uzyskania dowodu nabycia spadku należy wziąć udział w postępowaniu sądowym lub w odpowiednim postępowaniu przed notariuszem, co stało się możliwe od 24 VIII $2007 \mathrm{r}$. wskutek nowelizacji ustawy z dnia 14 II 1991 r. prawo o notariacie (Dz. U. 1991 nr 22 poz. 91 z późn. zm.). W przypadku postępowania sądowego odbywa się ono w trybie nieprocesowym przed sądem właściwym ustalonym wg art. $628 \mathrm{KPC}^{4}$. Postępowanie wszczynane jest na wniosek zainteresowanego podmiotu, przy czym należy stwierdzić, iż ustawodawca nie przewidział najpóźniejszego terminu początkowego, ani też terminu końcowego dla złożenia przedmiotowego wniosku. Ze względu na fakt, iż żądanie stwierdzenia nabycia spadku posiadające charakter roszczenia niemajątkowego nie podlega przedawnieniu' ${ }^{5}$, wszczęcie postępowania w tym przedmiocie może mieć miejsce nawet wiele lat po śmierci spadkodawcy. Należy jednakże pamiętać, że nie można stwierdzić nabycia spadku przed upływem sześciu miesięcy od dnia dowiedzenia się przez spadkobiercę o tytule swego powołania do spadku, chyba że wszyscy znani sądowi spadkobiercy złożyli oświadczenia o przyjęciu lub odrzuceniu spadku. Jest to termin minimalny, gdyż mogą wystąpić inne sytuacje uniemożliwiające sądowi wydanie postanowienia w przedmiocie stwierdzenia nabycia spadku, np. gdy spadkobiercy dowiedzieli się w różnym czasie o tytule swojego powołania z powodu odrzucenia spadku przez spadkobierców powołanych w pierwszej kolejności . Można zauważyć, że ta prawna regulacja może znaleźć zastosowanie w sytuacji, gdy zmianie ulega krag spadkobierców w trakcie okresu wskazanego w art. 1015 KC, np. w sytuacji, gdy wskutek stwierdzenia nieważności testamentu o tytule swojego powołania dowiedzieli się spadkobiercy ustawowi. W przypadku stwierdzenia przez sąd nabycia spadku przed upływem wskazanego $\mathrm{w}$ art. 1026 KC okresu, to ze względu na możliwe zajście modyfikacji kręgu spadkobierców, mogłaby często zachodzić potrzeba zmiany lub uchylenia postanowieniu o nabyciu spadku w drodze art. 679 KPC. Przyjęte przez ustawodawcę rozwiązanie zapobiega takim sytuacjom i pozwala jedynie na wyjątkowe wykorzystywanie przez sąd lub uczestników postępowania instytucji zmiany lub uchylenia postanowienia o nabyciu spadku ze względu na zmianę kręgu spadkobierców.

Wracając do kwestii wniosku inicjującego postępowanie, należy mieć na uwadze, że mogą go według prawa złożyć podmioty posiadające legitymację czynna, którymi $\mathrm{w}$ tym przypadku są osoby posiadające w stwierdzeniu dziedziczenia interes prawny (art. $1025 \S 1 \mathrm{KC}$ ). Według definicji przyjętej w doktrynie, osobą posiadająca interes prawny w postępowaniu w przedmiocie stwierdzenia nabycia spadku jest „,każda osoba, która zainteresowana jest w wywołaniu skutków, jakie ustawa łączy z wydaniem przez sąd postanowienia stwierdzającego nabycie spadku przez określone osoby"s. Można przyznać, iż w przypadku interesu prawnego chodzi o funkcję legitymacji procesowej, którą daje tylko interes prawny wiążący się z obiektywną potrzebą wszczęcia postępowania. ${ }^{9}$ Wskutek tego można uznać, iż podmiotami posiadającymi legitymację do złożenia wniosku są m.in.:

3 T. Demendecki, Komentarz aktualizowany do art. 669 KPC, [w:] A. Jakubecki (red.), Komentarz aktualizowany do ustawy z dnia 17 listopada 1964r. Kodeks postępowania cywilnego, Warszawa 2013.

4 H. Dolecki, Postępowanie cywilne. Zarys wyktadu, Warszawa 2013, s. 295.

5 A. Góra-Błaszczykowska (red.), Kodeks postępowania cywilnego. Komentarz do art. 1-729, T. I, Warszawa 2013.

6 B. Kordasiewicz (red.), Prawo spadkowe, Warszawa 2013.

7 E. Niezbecka, Komentarz do art.1026 Kodeksu cywilnego, [w:] A. Kidyba (red.), Kodeks cywilny. Komentarz. Spadki, T. IV, Warszawa 2011.

8 K. Osajda (red.), dz. cyt.

9 Postanowienie Sądu Najwyższego - Izba Cywilna z dnia 28 I 2009 r. o sygn. akt V CSK 361/08. 
- spadkobiercy,

- $\quad$ wierzyciele spadkobiercy,

- $\quad$ wierzyciele spadkodawcy,

- osoby nabywające przedmiot spadku,

- $\quad$ dłużnicy spadkowi ${ }^{10}$.

Podmiotem posiadającym interes prawny we wszczęciu postępowania może być również osoba, która przykładowo pragnie dowieść przed wierzycielami spadkodawcy, że nie stała się spadkobiercą i wskutek tego nie ponosi odpowiedzialności za długi spadkowe. W tym miejscu należy wyraźnie zaznaczyć, że w przywołanym przepisie „spadkobiercą” jest podmiot przekonany, że swoje uprawnienia do spadku wywodzi z ustawy lub z testamentu. Bez znaczenia pozostaje fakt, iż stan faktyczny może znacząco mijać się z wyobrażeniem wnioskodawcy w tym względzie. Jak można zauważyć, krąg podmiotów posiadających interes prawny w wydaniu postanowienia o stwierdzeniu nabycia spadku został ustalony przez ustawodawcę bardzo szeroko. Również szeroko ustanowiony został krąg osób zainteresowanych w sprawie, które na mocy art. 510 KPC mogą wziąć udział w sprawie jako uczestnicy. Można zaliczyć tu również wymienione wyżej podmioty, w tym pozostałych spadkobierców nie będących wnioskodawcami. Należy pamiętać, iż niestawiennictwo pozostałych uczestników nie tamuje rozpoznania sprawy (art. $513 \mathrm{KPC}$ ), niemniej wnioskodawca w określonych w art. $512 \mathrm{KPC}$ okolicznościach może wycofać wniosek tylko w przypadku braku wyrażenia przez nich sprzeciwu w wyznaczonym terminie. Nieco inne rozwiązanie przyjął ustawodawca w przypadku postępowania w przedmiocie uchylenia lub zmiany postanowienia o stwierdzeniu nabycia spadku, o czym będzie szerzej mowa poniżej.

Wprawdzie sąd w postępowaniu nieprocesowym co do zasady orzeka na posiedzeniach (art. 514 KPC a contrario), niemniej ze względu na brzmienie lex specialis $\mathrm{w}$ przypadku postępowania $\mathrm{w}$ przedmiocie stwierdzenia nabycia spadku sąd obligatoryjnie przeprowadza rozprawę (art. $514 \S 1 \mathrm{KPC}$ w zw. z art. 669 KPC). Wspomniana rozprawa w przypadku ogłoszenia w drodze art. 674 KPC powinna mieć miejsce po upływie terminu sześciu miesięcy od dnia jego dokonania ${ }^{11}$. Ponadto wszczęcie postępowania odbywa się głównie na wniosek i co do zasady sąd nie wszczyna postępowania z urzę$\mathrm{du}$ (wyjątkiem jest sytuacja przewidziana w art. $681 \mathrm{KPC}$ ). Na wskazaną w zdaniu poprzednim rozprawę powinny zostać wezwane, oprócz wnioskodawcy, również osoby, które zgłosiły żądanie oraz podały adres zamieszkania (art. $675 \mathrm{KPC}$ ). Ostrożnie interpretując przywołany przepis, należy stwierdzić, iż sąd nie powinien się w tym przypadku ograniczyć do uczestników wskazanych we wniosku, lecz powinien wezwać również osoby mogące być spadkobiercami, których istnienie wynika z późniejszych pism przygotowawczych oraz oświadczeń wnioskodawcy lub uczestników postępowania, a także osoby, o których w inny sposób sąd powziął wiadomośćc ${ }^{12}$.Znajduje to zastosowanie również w sytuacji, gdy spadkobierca pozostawił niebudzący wątpliwości co do swojej ważności testament, powoławszy w nim do całości spadku określone osoby ${ }^{13}$.

Sąd ma obowiązek zbadać z urzędu, kto zalicza się do kręgu spadkobierców. Może to być dokonane między innymi w drodze ustalenia przez sąd faktu pozostawienia testamentu przez spadkodawcę. Jeśli testament zostanie złożony przez osobę, która nim dysponuje, na sądzie spoczywa obowiązek dokonania jego otwarcia i ogłoszenia (art. 670 KPC). Ponadto sąd powinien z urzędu sprawdzić czy ktoś ze spadkobierców nie został uznany za niegodnego dziedziczenia, zaś w przypadku, gdy takie postępowanie się toczy, sąd może zawiesić postępowanie dotyczące stwierdzenia nabycia spadku. W celu trafnego ustalenia kręgu spadkobierców, sąd powinien nie tylko wyeliminować z tego grona spadkobierców niegodnych dziedziczenia, jak również spadkobierców, którzy odrzucili spadek oraz tych, co do których zachodzą okoliczności wyłączające ich od dziedziczenia ustawowego ${ }^{14}$. Jako dowód na okoliczność braku innych spadkobierców może zostać przyjęte oświadczenie złożone przez zgłaszającego się spadkobiercę, co reguluje art. $671 \mathrm{KPC}$. Oświadczający pod odpowiedzialnością karną wynikającą z ustawy powinien wyznać wszystko, co jest mu wiadome o istnieniu lub nieistnieniu osób, które wyłączałyby znanych spadkobierców od dziedziczenia lub dziedziczyłyby wraz z nimi, a także o informacjach, które posiada o testamentach pozostawionych przez spadkodawcę. W sytuacji, gdy m. in. takie zapew-

10 Oprócz wskazanych podmiotów wnioskodawca w przypadku spadku otwartego za granica, ale podlegającego polskiej jurysdykcji może być polskie przedstawicielstwo dyplomatyczne lub konsularne (art. 1109 KPC w zW. z art. 1108 § 1 KPC). Zob. A Góra-Błaszczykowska (red.), dz. cyt.

11 E. Marszałkowska-Krześ, Kodeks postępowania cywilnego. Komentarz, Warszawa 2013.

12 E. Marszałkowska-Krześ, Postẹpowanie cywilne, Warszawa 2013, s. 463.

13 J. Pietrzykowski, Art. 669 - posiedzenie sadowe, [w:] K. Piasecki (red.), Kodeks postępowania cywilnego. T. III, Warszawa 2010.

14 T. Żyznowski, Komentarz do art. 670 KPC, [w: H. Dolecki (red.), Kodeks postępowania cywilnego. Komentarz. Artykuty 506-729, T. III, Warszawa 2013.

OGRODY NAUK I SZTUK NR 2014 (4) 
nienie nie może zostać złożone lub w ocenie sądu nie jest wystarczające do stwierdzenia powyższych okoliczności, sąd ma obowiązek przed wydaniem postanowienia o nabyciu spadku wezwać spadkobierców przez ogłoszenie, w którym na mocy art. 673 KPC nakazuje spadkobiercom w terminie sześciu miesięcy od dnia wskazanego w ogłoszeniu zgłosić się i udowodnić nabycie spadku, gdyż pod rygorem pominięcia w postanowieniu o stwierdzeniu nabycia spadku. Ogłoszenie takie powinno zostać odpowiednio opublikowane, co reguluje art. $674 \mathrm{KPC}$, zaś po upływie terminu określonego w art. 675 KPC można wyznaczyć rozprawę w celu rozpoznania zgłoszonych żądań.

Postanowienie o nabyciu spadku przez spadkobierców, których prawa zostały wykazane, powinno być zgodnie z art. 676 KPC wydane, jeśli w ciągu sześciu miesięcy od dnia ogłoszenia o wezwaniu spadkobierców nikt nie zgłosił nabycia spadku, a także, gdy je zgłosiwszy, nie udowodnił ich na rozprawie. Warto zauważyć, że wspomniany termin ma charakter deklaratoryjny, wobec czego, gdy przed wydaniem postanowienia spadkobierca zgłosi się po upływie terminu i udowodni swoje roszczenia do przedmiotu spadku, sąd ma obowiązek stwierdzić nabycie przez niego spadku' ${ }^{15}$. W postanowieniu o nabyciu spadku sąd wymienia przede wszystkim spadkodawcę oraz wszystkich spadkobierców, choćby były to inne osoby niż wskazane przez wnioskodawcę, a także wielkość udziałów spadkowych. Ponadto we wskazanym postanowieniu powinno znaleźć się stwierdzenie nabycia przedmiotu zapisu windykacyjnego wraz z wymienieniem zapisobiercy oraz przedmiotu zapisu windykacyjnego (art. 677 § 2 KPC). Koresponduje to w pełni z obowiązkami sądu wynikającymi z przywołanych wcześniej przepisów, m. in. art. $670 \mathrm{KPC}$.

ZMIANA KRĘGU SPADKOBIERCÓW PO WYDANIU POSTANOWIENIA O NABYCIU SPADKU

Wprawdzie ustawodawca poprzez wskazane w poprzednim rozdziale uregulowania prawne starał się zapobiec rozbieżności pomiędzy rzeczywistym kręgiem spadkobierców oraz wysokością ich udziałów spadkowych, a kręgiem wynikającym z postanowienia sądu, niemniej nie zawsze w praktyce uda się tego uniknąć. Przede wszystkim w trakcie postępowania o stwierdzenie nabycia spadku mogą nie ujawnić się wszystkie okoliczności powodujące zmianę potencjalnego spadkobierców, w wyniku których do dziedziczenia powinni przykładowo dojść:

- nieznani wcześniej spadkobiercy,

- $\quad$ spadkobiercy dziedziczący w dalszej kolejności,

- $\quad$ spadkobiercy testamentowi,

- $\quad$ spadkobiercy ustawowi.

Może to być wynikiem stwierdzenia istnienia dzieci pozamałżeńskich, wystąpienia przyczyn skutkujących wyłączeniem niektórych spadkobierców od dziedziczenia (np. odrzucenie spadku), ustalenia faktu sporządzenia przez spadkodawcę testamentu, a także przyczyn skutkujących nieważnością testamentu. Katalog okoliczności mogących powodować zmianę kręgu spadkobierców po wydaniu przez sąd postanowienia jest otwarty. Poza tym należy zauważyć, iż w trakcie prowadzenia postępowania jego uczestnicy oraz sąd nie tylko mogą nie posiadać wiedzy o wskazanych okolicznościach, ale także sąd może nie wykryć tychże okoliczności ze względu na niekompletny materiał dowodowy. Może zajść również sytuacja, w której spadkobiercy wezwani za pomocą ogłoszenia nie ujawnią się przed wydaniem postanowienia o nabyciu spadku, wskutek czego na mocy art. $673 \mathrm{KPC}$ mogą zostać pominięci we wskazanym postanowieniu. Niemniej wskutek art. $925 \mathrm{KC}$ spadkobierca nabywa spadek z chwilą jego otwarcia, wskutek czego należy uznać, iż postanowienie o nabyciu spadku ma charakter deklaratoryjny i nie pozbawia spadkobiercy jego prawdo spadku. Można zatem zadać pytanie o spójność regulacji prawa cywilnego materialnego i procesowego w kwestii stwierdzenia nabycia spadku.

W poprzednim rozdziale ukazano skutki zgłoszenia się nowych spadkobierców przed wydaniem przez sąd postanowienia o nabyciu spadku, co mogło wywrzeć wpływ na krag spadkobierców ustalony we wskazanym postanowieniu oraz wartość ich udziałów w spadku. Niestety, rozwiązanie to nie może znaleźć zastosowania w sytuacji, gdy postanowienie zostało wydane, a mało tego - stało się prawomocne. Zgodnie z art. 523 KPC prawomocne postanowienie orzekające co do istoty sprawy nie podlega zmianie ani uchyleniu, chyba że przepis szczególny stanowi inaczej. Art. 679 KPC ma charakter lex specialis do wskazanego przepisu, wskutek czego możliwa jest zmiana lub uchylenie prawomocnego postanowienia o nabyciu spadku wówczas, gdy osoba, która uzyskała stwierdzenie nabycia spadku nie jest spadkobiercą lub jej udział spadkowy jest mniejszy niż stwierdzono w postanowieniu. Wspomnieć należy, iż niemożliwa jest w tym przypadku skarga o wznowienie postępowania ze względu na brzmienie art. $524 \S 1 \mathrm{KPC}$, co budzi kontrowersje w doktrynie w przypadku konieczności uchylenia lub zmiany kilku postanowień o nabyciu spadku po tym samym spadkodawcy ${ }^{16}$.

15 E. Marszałkowska-Krześ, Kodeks postępowania..., dz. cyt.

16 T. Demendecki, dz. cyt. 
Uznaje się również, że dyspozycja art. 679 KPC przemawia za traktowaniem wyrażonej w nim instytucji jako zastępującej wznowienie postępowania $\mathrm{w}$ tym zakresie ${ }^{17}$. Ze względu na fakt, iz jest to $\mathrm{w}$ dalszym ciągu postępowanie o stwierdzenie nabycia spadku, zastosowanie znajdują w świetle art. $679 \mathrm{KPC}$ odpowiednio art. 669-678 $\mathrm{KPC}^{18}$.

Na podstawie art. 679 § 1 KPC zd. 2 a contrario można zauważyć, że termin na złożenie wniosku o uchylenie lub zmianę postanowienia o nabyciu spadku znajduje zastosowanie tylko do jednej z wymienionych $\mathrm{w}$ przepisie kategorii wnioskodawców, mianowicie tych, którzy byli wcześniej uczestnikami postępowania. Powinni oni złożyć wniosek w terminie roku od dnia, w którym mieli możność powołać się na podstawę swojego wniosku, czyli wszystkie okoliczności faktycznei zdarzenia prawne mające znaczenie dla ustalenia porządku dziedziczenia ${ }^{19}$. Należy przyznać, iż termin ten ma charakter zawity. W przypadku wnioskodawców, którzy nie byli wcześniej uczestnikami postępowania ustawodawca nie przewidział ograniczenia terminem, co nie tylko koreluje z art. $925 \mathrm{KC}$, ale również podkreśla ochronną rolę tego przepisu. Jak można wywnioskować na podstawie powyższych rozważań, wnioskodawcami w przypadku zmiany lub uchylenia postanowienia o nabyciu spadku mogą być:

- wnioskodawcy będący wcześniej uczestnikami postępowania w przedmiocie stwierdzenia nabycia spadku,

- wnioskodawcy, którzy nie byli wcześniej wyżej wskazanymi uczestnikami,

- inne podmioty.

Przedmiotową kwestię reguluje art. 679 § 2 KPC, w którym ustawodawca przyznał legitymację do wystapienia $\mathrm{z}$ takim wnioskiem każdemu zainteresowanemu, którym może być każda osoba mająca interes prawny lub majątkowy w wykazaniu określonego następstwa prawnego po spadkodawcy. Można więc uznać, że pojęcie zainteresowanego należy interpretować szeroko, gdyż oprócz spadkobierców, wierzycieli spadkodawcy, wykonawcy testamentu i innych podmiotów ${ }^{20}$, zainteresowaną $\mathrm{w}$ ustaleniu następstwa prawnego może być również instytucja państwowa, przykładowo organ podatkowy, o czym w dalszej części artykułu. Osoba zainteresowana powinna jednak dysponować dowodem na okoliczność, że osoba widniejąca w postanowieniu o nabyciu spadku nie jest spadkobiercą lub jej udział w spadku jest inny niż ustalony. Należy uznać, że zakres pojęcia „każdego zainteresowanego” z art. 679 §2 KPC wedle wskazań przedstawicieli doktryny pokrywa się znaczeniowo z pojęciem „,osoby posiadającej interes prawny" z art. $1025 \mathrm{KC}$, wobec czego mamy do czynienia z podobną regulacją jak w przepisach dotyczących postępowania o stwierdzenie nabycia spadku²1.

Do ciekawych wniosków można dojść w kwestii pozycji stron w dowodzeniu w trakcie postępowania o zmianę lub uchylenie stwierdzenia nabycia spadku. Przede wszystkim osoby ustalone jako spadkobiercy w stwierdzeniu nabycia spadku korzystają z domniemania bycia spadkobiercą wynikającego z art. 1025 § $2 \mathrm{KC}$, które może zostać obalone tylko w postępowaniu o zmianę lub uchylenie postanowienia o nabyciu spadku. W związku z tym onus probandi ciąży na wnioskodawcy, który stara się dowieść odmiennego stanu prawnego niż wynikającego z postanowienia sądu. Właśnie w kwestii dowodów zaznacza się odmienne stanowisko pomiędzy wnioskodawcami będącymi wcześniej uczestnikami postępowania o stwierdzenie nabycia spadku, a wnioskodawcami nieuczestniczącymi w poprzednim postępowaniu. Pierwsi z wymienionych mogą złożyć wniosek o zmianę lub uchylenie wspomnianego postanowienia tylko wówczas, gdy żądanie swoje opierają podstawie, której nie mogli powołać podczas postępowania o stwierdzenie nabycia spadku, czyli przedstawiane przez nich dowody mogą dotyczyć tylko i wyłącznie tejże podstawy. Warto zaznaczyć, iż powyższe rozważania dotyczą nie tylko do zmiany postanowienia o nabyciu spadku, lecz również zmiany dalszego postanowienia zmieniającego $0^{22}$. Kontrowersje dotyczą ograniczeń zstępnych uczestnika postępowania o stwierdzenie nabycia spadku w kwestii dowodzenia ${ }^{23}$. Pozostali wnioskodawcy mogą powoływać się na każdą okolicznośći nie znajdują w tym ograniczenia ze strony ustawy, co jest zgodne z gwarancyjnym charakterem analizowanego przepisu, który przejawia się w pełni w jego $§$.

Jeżeli wnioskodawca przedstawi wiarygodny dowód na poparcie swojego twierdzenia, związanego z nabyciem spadku przez inną osobę niż wskazaną w prawomocnym postanowieniu o stwierdzeniu nabycia spadku, sąd ma obowiązek $\mathrm{z}$ urzędu zmienić to postanowienie oraz stwierdzić zgodnie z rzeczywistym stanem prawnym nabycie spadku (art. 679 §

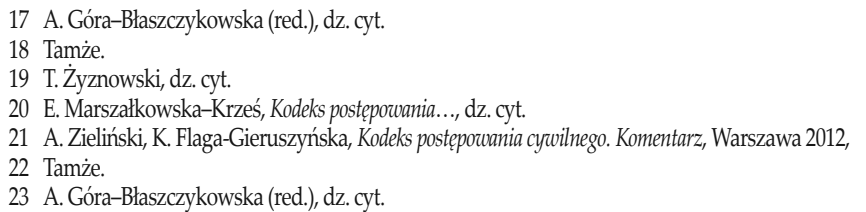

OGRODY NAUK I SZTUK NR 2014 (4) 
$3 \mathrm{KPC})$. Dotyczy to oczywiście również sytuacji, w której udowodnione zostanie, że osoba legitymująca się stwierdzeniem nabycia spadku lub aktem poświadczenia dziedziczenia nabyła spadek $w$ innym udziale niż wskazany w powyższych dokumentach. Jak można zauważyć, ustawodawca podkreślił tu charakter unormowania, które pozwala naprawićbłędne ustalenie rzeczywistego stanu prawnego. Należy z całą mocą podkreślić, iż postępowanie w trybie art. 679 KPC nie ma na celu korekcji skutków bezczynności stron lub popełnionych przez nich błędów w trakcie postępowania o stwierdzenie nabycia spadku². Zgodnie z art. 679 § 3 KPC przedstawiony tryb postępowania należy stosować również do zmiany lub uchylenia aktu poświadczenia dziedziczenia oraz stwierdzenia nabycia przedmiotu zapisu windykacyjnego, co jest konsekwencją wprowadzenia powyższych instytucji do obrotu.

\section{KONIECZNOŚĆ ZAWIESZENIA LUB WZNOWIENIA POSTĘPOWANIA PODATKOWEGO}

Uzyskanie postanowienia o nabyciu spadku pozwala na zadziałanie domniemania z art. $1025 \mathrm{KC}$, a także umożliwia wszczęcie postępowania w przedmiocie ustalenia podatku od spadków i darowizn w świetle przepisów ustawy z dnia 28 VII 1983 r. o podatku od spadku i darowizn (Dz. U. 2009 nr 93, poz. 768 -j. t., ze zm.). W kwestii wskazanego postępowania mogą wyjść na jaw istotne okoliczności faktyczne, nieznane w dniu jego wszczęcia przy czym powstają zupełnie inne skutki w świetle przepisów ustawy z dnia 29 VIII 1997r. ordynacja podatkowa (Dz. U. z 2012r. poz. 749) w zależności czy do zmiany kręgu spadkobierców dojdzie w trakcie postępowania podatkowego, czy po prawomocnym jego zakończeniu w postaci wydania decyzji ustalającej podatek od spadków i darowizn.

Szczególna sytuacja ma miejsce, gdy organ podatkowy poweźmie informacje o okolicznościach mających wpływ na ustalenie kręgu spadkobierców, w szczególności na zmianę składu personalnego lub zmianę wysokości udziałów w spadku. Organ powinien wówczas rozważyć zawieszenie prowadzonego postępowania. Na podstawie art. $201 \S 1$ pkt. 2 ustawy z dnia 29 VIII 1997 r. ordynacja podatkowa (Dz. U. z 2012r. poz. 749) jest to możliwe ze względu na konieczność rozstrzygnięcia zagadnienia wstępnego przez właściwy sąd powszechny, jeśli rozpatrzenie sprawy lub wydanie decyzji przez organ podatkowy jest od tego uzależnione. Z brzmienia art. 202 \$1 a contrario wynika, iż organ nie ma możliwości przeprowadzania czynności innych niż mających na celu podjęcie zawieszonego postępowania lub zabezpieczenie dowodu. Na organie podatkowym ciąży na mocy art. 203 § 1 obowiązek wezwania stron postępowania do wystąienia w oznaczonym terminie do sądu o zmianę lub uchylenie postanowienia o nabyciu spadku. Niemniej, gdy strona wykaże, że złożyła wniosek w trybie art. 679 KPC organ podatkowy nie ma obowiązku wystosowywać wobec niej wskazanego w zdaniu poprzednim wezwania. Ponadto w przypadku bezskutecznego upływu wyznaczonego terminu, organ podatkowy powinien z urzędu wystąicić z wnioskiem do sądu o zmianę lub uchylenie postanowienia o nabyciu spadku, przy czym należy w tym przypadku przyznać mu pełną legitymację procesowąa stwierdzić, iż legitymacja procesowa nie wynika z art. 203 § 2 ordynacji podatkowej, który nie stanowi jej uniwersalnej podstawy prawnej, ale z przepisu szczególnego, którym w tym przypadku będzie art. 679 § $2 \mathrm{KPC}$, zaś organ podatkowy mieści się w pojęciu „,każdego zainteresowanego" ${ }^{\prime 26}$. Jeśli dojdzie do uprawomocnienia się postanowienia sądu o zmianie lub uchyleniu stwierdzenia nabycia spadku, organ podatkowy powinien na podstawie art. 205a §1 pkt. 4 z urzędu podjąć zawieszone postępowanie, gdy powziął wiadomość o wskazanym uprawomocnieniu, w celu jego dalszego prowadzenia i zakończenia stosowną decyzja.

Inna konieczność zajdzie w przypadku, gdy okoliczności uzasadniające zmianę lub uchylenie stwierdzenia nabycia spadku stały się wiadome po wydaniu prawomocnej decyzji ustalającej podatek od spadków i darowizn. Gdy spadkobierca uzyskał w drodze postępowania z art. 679 KPC stwierdzenie nabycia spadku powinien wystąić do organu podatkowego o wznowienie postępowania w trybie art. $243 \mathrm{w}$ zw. $\mathrm{z}$ art. $240 \S 1 \mathrm{pkt} .7$ ordynacji podatkowej. Organ podatkowy ma wówczas obowiązek zbadać przede wszystkim czy zachodzą przesłanki z art. 240 uzasadniające wznowienie postępowania, w tym przypadku czy wspomniana decyzja ustalająca podatek od spadków i darowizn została wydana na podstawie postanowienia sądu o nabyciu spadku, które następnie zostało uchylone lub zmienione w sposób mogący mieć wpływ na treść wydanej decyzji. Zaznaczyć należy przy tym, że postanowienie sądu o zmianie lub uchyleniu stwierdzenia nabycia spadku jest orzeczeniem, które stanowi podstawę prawną wydanej decyzji podatkowej zgodnie ze stanowiskiem zajętym przez Naczelny Sąd Administracyjny w wyroku z dnia 9 IV2003 r. o sygn. akt III SA 1933/01. Inicjatywa

25 M. Bogucka, Komentarz do art. 203 Ordynacji podatkowej, [w:] H. Dzwonkowski (red.), Ordynacja podatkowa. Komentarz, Warszawa 2013.

26 J. Brolik, R. Dowgier, L. Etel, C. Kosikowski, P. Pietrasz, M. Popławski, S. Presnarowicz, W. Stachurski, Ordynacja podatkowa. Komentarz,
} Warszawa 2013. 
w kwestii wznowienia postępowania należy zarówno do strony postępowania, jak i organu podatkowego. Jeśli występuje przesłanka z art. 240 § 1 pkt. 7, organ podatkowy, który wydał decyzję w ostatniej instancji wydaje zgodnie z art. 243 § 1 postanowienie o wznowieniu postępowania podatkowego. Wskazane postanowienie stanowi wówczas podstawę do rozstrzygnięcia przez organ co do przesłanek wznowienia oraz co do istoty sprawy.

W sytuacji, gdy w ocenie organu podatkowego wystapiła przesłanka obligująca go do wznowienia postępowania, powinien on zgodnie z art. $245 \S 1$ pkt. 1 uchylić $w$ całości lub w części dotychczasową decyzję, a także orzec co do istoty sprawy lub umorzyć postępowanie w sprawie. Należy przyznać, że do umorzenia postępowania dojdzie wobec stron, które z powodu zmiany kręgu spadkobierców nie są uprawnione do dziedziczenia. Można zastanowić się w tym momencie nad kwestią zwrotu podatku, do którego powinno dojść w sytuacji, gdy strona zapłaciła większy podatek niż powinna wskutek zmiany postanowienia o nabyciu spadku. Na mocy art. $75 \S 1 \mathrm{w} z w . \mathrm{z}$ art. $73 \S 1$ ordynacji podatkowej podatnik ma prawo złożenia wniosku o stwierdzenie nadpłaty, zaś organ podatkowy w przypadku spełnienia się przesłanek z art. $75 \S 4$ powinien zwrócić nadpłatę bez wydania decyzji jej stwierdzającej. Jeżeli podatnik zapłacił podatek w wysokości mniejszej niż powinien, zobligowany jest do jego uzupełnienia w określonym terminie. Warty zaznaczenia jest fakt, że jeśli okoliczności sprawy wskazują na prawdopodobieństwo uchylenia decyzji w wyniku wznowienia postępowania, organ podatkowy ma obowiązek wstrzymania z urzędu lub na wniosek strony wykonanie decyzji (art. 246 §1 Ordynacji podatkowej). Na wyżej wskazane postanowienie organu podatkowego służy zażalenie, poza przypadkiem, gdy zostało ono wydane przez organy wskazane w art. $246 \S 2$ Ordynacji podatkowej.

\section{ZAKOŃCZENIE}

Zmiana kręgu spadkobierców, powodująca istotne implikacje na gruncie materialnego prawa cywilnego w szczególności w kwestii wynikających z niego domniemań prawnych nie pozostaje bez wpływu na sferę prawa procesowego, co $\mathrm{w}$ niniejszym artykule starano się wykazać $\mathrm{w}$ świetle odpowiednich uregulowań prawnych postępowania cywilnego oraz postępowania podatkowego. Ze względu na fakt, że stwierdzenie nabycia spadku pozwala na zastosowanie wobec legitymującego się nim podmiotu domniemania z art. 1025 §1 KC, każda zmiana kręgu spadkobierców lub ich udziałów w spadku powinna znaleźć odzwierciedlenie w postanowieniu o nabyciu spadku. Jest ono bowiem często podstawą prawną do dokonania wielu czynności prawnych, takich jak wpis do Księgi Wieczystej lub udziału w postępowaniu przed organem podatkowym.

Na podstawie wniosków wynikających z niniejszego artykułu należy uznać, iż w powyższym celu należy przeprowadzić postępowanie o zmianę lub uchylenie stwierdzenia nabycia spadku w świetle odpowiednich regulacji Kodeksu postępowania cywilnego w przypadku, gdy okoliczności to uzasadniające stały się wiadome po uprawomocnieniu się postanowienia o nabyciu spadku. Mimo, iż jest to w dalszym ciągu postępowanie o stwierdzenie nabycia spadku, na uwagę zasługują odrębności przejawiające się przede wszystkim w innej pozycji spadkobierców w kwestii terminów na złożenie wniosku oraz możliwości powoływania określonych dowodów. W przypadku, gdy wskazane powyżej przyczyny stały się wiadome $\mathrm{w}$ trakcie trwania postępowania o stwierdzenia nabycia spadku, nie ma konieczności sięgnięcia do art. 679 KPC, gdyż sąd przy wydaniu orzeczenia weźmie pod uwagę zgłoszonych spadkobierców oraz wielkość ich udziału w spadku.

Analogicznie, $\mathrm{w}$ trakcie postępowania podatkowego stanie się wiadome, że stan prawny wynikający z postanowienia o nabyciu spadku jest niezgodny z rzeczywistościa, organ podatkowy powinien zawiesić postępowanie w celu wyjaśnienia tej kwestii przez sąd powszechny. Po podjęciu zawieszonego postępowania organ podatkowy weźmie pod uwagę rozstrzygnięcie sądu, wskutek czego nie występują przesłanki do wznowienia postępowania. Zaistnieją one, gdy do zmiany lub uchylenia postanowienia o nabyciu spadku dojdzie po uprawomocnieniu się decyzji ustalającej podatek od spadków i darowizn. Można zatem zauważyć spójność regulacji cywilnych i podatkowych oraz dostrzec w nich zamysł ustawodawcy, przejawiający sięnie tylko w funkcji ochronnej, ale przede wszystkim w dążeniu do zapewnieniu zgodności stanu prawnego wynikającego z orzeczeń oraz decyzji organów państwowych ze stanem występującym w rzeczywistości.

\section{BIBLIOGRAFIA}

\section{Teksty źródłowe/akty prawne}

[1] Ustawa z dnia 17 XI 1964 kodeks postępowania cywilnego (Dz. U. z 1964r. nr 43 poz. 296 -j. t. z późn. zm.).

[2] Ustawa z dnia 28 VII 1983 r. o podatku od spadku i darowizn (Dz. U. 2009 nr 93, poz. 768 -j.t., z późn. zm.).

[3] Ustawa z dnia 29 VIII 1997r. ordynacja podatkowa (Dz. U. z 2012r. poz. 749). 


\section{Książki/czasopisma}

[4] Bogucka M., Komentarz do art. 203 Ordynacji podatkowej, [w:] Dzwonkowski H. (red.), Ordynacja podatkowa. Komentarz, Warszawa 2013.

[5] Brolik J., Dowgier R., Etel L., Kosikowski C., Pietrasz P., Popławski M., Presnarowicz S., Stachurski W., Ordynacja podatkowa. Komentarz, Warszawa 2013.

[6] Demendecki T., Komentarz aktualizowany do art. 669 KPC, [w:] Jakubecki A. (red.), Komentarz aktualizowany do ustawy z dnia 17 listopada 1964 r. Kodeks postepowania cywilnego, Warszawa 2013.

[7] Dolecki H., Postepowwanie cywilne. Zarys wykładu, Warszawa 2013.

[8] Góra-Błaszczykowska A. (red.), Kodeks postẹpowania cywilnego. Komentarz do art. 1-729. T. I, Warszawa 2013.

[9] Kordasiewicz B.(red.), Prawo spadkowe, Warszawa 2013.

[10] Marszałkowska-Krześ E., Kodeks postępowwania cywilnego. Komentarz, Warszawa 2013.

[11] Marszałkowska-Krześ E., Postepowanie cywilne, Warszawa 2013.

[12] Niezbecka E., Komentarz do art.1026 Kodeksu cywilnego, [w:] Kidyba A. (red.), Kodeks cywilny. Komentarz. Spadki, T. IV, Warszawa 2011.

[13] Osajda K. (red.), Kodeks cywilny. Komentarz, Warszawa 2013.

[14] Pietrzykowski J., Art. 669 - posiedzenie sadowe, [w:] Piasecki K. (red.), Kodeks postępowania cywilnego. T. III, Warszawa 2010.

[15] Skowrońska-Bocian E., Prawo spadkowe, Warszawa 2012.

[16] Żyznowski T., Komentarz do art. 670 KPC, [w:] Dolecki H. (red.), Kodeks postępowania cywilnego. Komentarz. Artykuly 506-729, T. III, Warszawa 2013. 